\title{
Invitro Evaluation of Botanicals and ITKs against Septoria lycopersici Causing Septoria Leaf Spot of Tomato
}

\author{
D. R. Sindushree*, Gurudatt M. Hegde and Yashoda R. Hegde
}

Department of Plant Pathology, College of Agriculture, Dharwad University of Agricultural Sciences, Dharwad-580 005, Karnataka, India

*Corresponding author

\section{Keywords}

Tomato, Septoria lycopersici, In vitro, Botanicals, ITKs

\section{Article Info}

\section{Accepted:}

04 March 2020 Available Online: 10 April 2020

\section{A B S T R A C T}

Tomato (Solanum lycopersicum L.) is one of the commercially important major vegetable crops grown throughout the tropics and subtropics. Septoria leaf spot caused by Septoria lycopersici Speg. is one of the most destructive diseases of tomato and is particularly severe in areas where wet, humid weather persists for extended periods. The bio assay of botanicals and Indigenous technical knowledge (ITKs) forms the prerequisite for the field evaluation. In the present investigation eight botanicals and eight ITKs were evaluated at 5, 10 and 15 per cent concentration against $S$. lycopersici under laboratory condition. Among the eight botanicals, Allium sativum (Garlic) bulb extract found to be significantly superior over other treatments in inhibiting the mycelial growth (65.10\%) of S. lycopersici followed by Duranta goldiana (Duranta) leaf extract $(53.73 \%)$ and lowest inhibition was observed in Tagates erecta (Marigold) leaf extract $(23.53 \%)$ at 15 per cent concentration. In vitro spore germination bioassay of ITKs revealed that, highest inhibition (76.67\%) of conidial germination over control was shown by Cow urine which was on par with Panchagavya (73.33\%) and the least inhibition was observed in biodigestor $(33.33 \%)$ at 15 per cent concentration.

\section{Introduction}

Tomato (Solanum lycopersicum L.) is one of the most remunerative and widely grown vegetables in the world. It is cultivating extensively for its edible fruits, which are rich source of vitamin A and C. Fruit is bright red due to the pigment lycopene, which is the major carotenoid in tomatoes, exhibits the highest antioxidant activity and it is a beneficial colouring agent for food because of its solid color and nontoxicity (Schulzova and Hajslova, 2007).

In India, the crop is being cultivated in a variety of climate, across states of Maharashtra, Andhra Pradesh, Karnataka, West Bengal, Odisha, Bihar, Madhya Pradesh, Uttar Pradesh, Gujarat and Chhattisgarh. 
Tomato production is hampered by a variety of plant pathogens such as bacterial, fungal, nematode and viral diseases and also by abiotic factors (Blancard et al., 1992). Fungal diseases like damping-off, late blight, early blight, powdery mildew, fusarium wilt, grey leaf spot, anthracnose, septoria leaf spot, buckeye rot (Sokhi et al., 1991) are the major biotic threats for tomato cultivation.

Among the fungal foliar diseases, Septoria leaf spot (Septoria lycopersici Speg.) of tomato is one of the devastating diseases of tomato causing yield loss up to 12 to 16 per cent (Rizinski, 1966). Extensive periods of more relative humidity, leaf wetness and temperatures of 20 to $25^{\circ}$ Care favourable environments for progress and spread of the pathogen (Weber, 1982; Elmer and Ferrandino, 1995). Symptoms generally include circular or angular lesions of about 1.5 to $6 \mathrm{~mm}$ in width with gray centers, dark brown margins and are most commonly found on the older, lower leaves of the plant. Small pycnidium fruiting bodies can be seen dispersed on the spots with rare infection on fruits.

Although, satisfactory control of the disease by using various chemicals has been documented (Choulwar and Datar, 1988; Maheshwari et al., 1991), the continuous use of these agrochemicals for controlling the disease may pose several problems like toxicity to non-target organisms, development of resistance in the populations of the pathogen and environmental pollution.

Use of botanicals is a cost effective, ecofriendly measure in plant disease management because they are easily biodegradeable and plants synthesize aromatic secondary metabolite like phenolic acids, phenols, flavones, flavonols, flavonoids, quinones, coumarins and tannins and these compounds serves as plant defence mechanisms against pathogenic microorganisms (Cowan, 1999). Another environmentally safe practice in plant disease management is the use ITKs (Indigenous technical knowledge) such as use of cow urine, cow dung, panchagavya, jeevamruta, vermiwashetc., which are reported to have antifungal activity against the pathogens (Raut and Vaidya, 2018). Hence, the use of the botanicals and ITKs needs more research as an eco-friendly measure for managing the fungal diseases of plants which can even be used as one of the components in integrated disease management.

\section{Materials and Methods}

\section{Evaluation of botanicals}

Fresh leaves of Pongamia pinnata, Duranta goldiana, Bougainvillea glabra, Eucalyptus globule, Tagates erecta and fresh bulbs of Allium sativum, Allium cepa were collected from different locations of Dharwad. Hundred grams of the fresh leaves/bulbs were washed with water, air dried and crushed in a mortar and pestle by adding sterile distilled water at the rate of $100 \mathrm{ml} / 100 \mathrm{~g}$ of plant tissue and homogenized in an electric blender. The homogenate was filtered out through double layer of muslin cloth and centrifuged at 5000 rpm for 5 minutes. The supernatant was collected and filtered through Whitman number 1 filter paper to avoid microbial contamination.

For preparation of Neem seed kernel extract, dried neem seeds were taken and washed thoroughly and then air dried. Known quantity of kernel (100g) were weighed, grinded the kernels gently to powder it and then soaked in same quantity $(100 \mathrm{ml})$ of water for $24 \mathrm{~h}$. Stirred and filtered twice with double layer of muslin cloth, centrifuged at $5000 \mathrm{rpm}$ for 5 minutes. The supernatant was collected and filtered through Whitman number 1 filter paper. 
The resultant extracts were considered as 100 per cent concentration (Stock solution). Later, from that stock solution, working solutions of required concentration were made. These extracts were evaluated at three concentrations $(5,10$, and $15 \%)$ using poison food technique (Shravelle, 1961) against $S$. lycopersici.

Potato dextrose agar was used as nutrient medium and required quantity of each plant extract was added separately so as to get a requisite concentration of the plant extract. 20 $\mathrm{ml}$ of poisoned medium was poured to each of the $85 \mathrm{~mm}$ petri dishes and allowed for solidification.

The actively growing hyphal bit $(5 \mathrm{~mm})$ from periphery of the seven day old culture of $S$. lycopersici was carefully cut using a cork borer and transferred aseptically to the centre of each petri dish containing the poisoned medium. Suitable control was maintained by growing the cultures on PDA without the plant extract. The plates were incubated at 27 $\pm 1{ }^{0} \mathrm{C}$ for seven days and the colony diameter was recorded.

Per cent inhibition over control was worked out according to formula given by Vincent (1947).

$$
I=\frac{(C-T)}{C} \times 100
$$

Where, $\mathrm{I}=$ Per cent inhibition of mycelial growth, $\mathrm{C}=$ Radial growth in control $(\mathrm{mm})$, $\mathrm{T}=$ Radial growth in treatment $(\mathrm{mm})$

\section{Evaluation of ITKs}

ITKs viz; jeevamrutha, panchgavya, vermiwash, biodigestor, buttermilk, cow urine, turmeric and ginger was collected from the bioresourse farming unit, Institute of Organic Farming, UAS, Dharwad and used for laboratory studies. These products were evaluated in vitro against the pathogen at 5, 10 and 15 per cent concentrations against $S$. lycopersici.To study the antifungal activity of ITKs and also the effective concentration, cavity slide method was followed as suggested by Nene and Thapliyal (1982).

Working solutions of 5, 10 and 15 per cent concentrations were made from the stock solution with sterile distilled water and these concentrations were tested in vitro on the germination of conidia of S. lycopersici. Each ITKs concentration was replicated three times. Germination of conidia was recorded after $24 \mathrm{~h}$ of incubation in moist chamber at room temperature. Spores incubated in sterile distilled water served as control. Per cent inhibition over control was calculated by using the formula given by Vincent (1947).

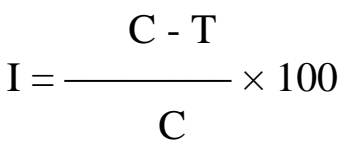

Where, $\mathrm{I}=$ Per cent inhibition of spore germination, $\mathrm{C}=$ Germination of spores in control

$\mathrm{T}=$ Germination of spore in treatment

\section{Results and Discussion}

\section{Evaluation of botanicals}

Present experiment was conducted to know the antifungal action of eight botanicals at three different concentrations 5, 10 and 15 per cent against S.lycopersici by using poison food technique as stated in Material and Methods.

The results reveled that, among the three concentrations tested, all the treatments recorded significantly higher inhibition of the pathogen at 15 per cent concentration followed by 10 per cent and 5 per cent 
concentrations (Plate 1). Among the eight botanicals tested against $S$. lycopersici highest per cent growth inhibition of mycelium was exhibited by Allium sativum bulb extract $(65.10 \%)$ was significantly superior over other treatments followed by Duranta goldiana leaf extract (53.73\%), Allium cepa bulb extract (51.76\%), Eucalyptus globule (50.59\%), Pongamia pinnata (47.84\%), Neem seed kernel extract (41.57\%), Bougainvillea glabra $(36.08 \%)$ and lowest inhibition was observed in Tagates erecta leaf extract $(23.53 \%)$ at 15 per cent concentration. The results are presented in Table 1 and Figure 1.

The results are in accordance with Lal, M. et al., (2016) found that, Neem (Azadirachta indica) was most effective in in inhibiting the fungal growth $(47.13 \%)$ of $S$. lycopersici followed by Ginger (Zingiber officinale) 45.98 per cent, garlic (Allium sativum L.) 43.68 per cent and onion (Allium cepaL.) 41.37 per cent.

Pankaj and Singh (2017) reported that, the Allium sativum extract was one of the effective botanical for management of early blight (A. solani). Roopa et al., 2014, reported that garlic (37.04\%), duranta $(34.44 \%)$ and neem leaf extract $(32.41 \%)$ at 10 per cent were effective in inhibiting the mycelial growth of $A$. solani. Garlic bulb extract is known to have antifungal activity against $C$. capsici(Murthy and Amonker, 1974). Singh et al., (1990) reported that a compound ajoene, derived from garlic inhibited Colletotrichum spp.

Table.1 In vitro evaluation botanicals against Septoria lycopersici

\begin{tabular}{|c|c|c|c|c|c|}
\hline \multirow[t]{2}{*}{ Treatments } & \multirow[t]{2}{*}{ Botanicals } & \multicolumn{4}{|c|}{ Per cent inhibition of mycelial growth } \\
\hline & & $5 \%$ & $10 \%$ & $15 \%$ & Mean \\
\hline $\mathbf{T}_{1}$ & Allium sativum & $\begin{array}{c}26.27 \\
(30.84)^{*}\end{array}$ & $\begin{array}{c}49.41 \\
(44.66)\end{array}$ & $\begin{array}{c}65.10 \\
(53.79)\end{array}$ & $\begin{array}{c}46.93 \\
(43.24)\end{array}$ \\
\hline $\mathbf{T}_{2}$ & Duranta goldiana & $\begin{array}{l}25.10 \\
(30.06)\end{array}$ & $\begin{array}{c}42.35 \\
(40.60)\end{array}$ & $\begin{array}{c}53.73 \\
(47.14)\end{array}$ & $\begin{array}{l}40.39 \\
(39.46)\end{array}$ \\
\hline $\mathbf{T}_{3}$ & Allium сера & $\begin{array}{c}20.78 \\
(27.13)\end{array}$ & $\begin{array}{c}40.39 \\
(39.46)\end{array}$ & $\begin{array}{c}51.76 \\
(46.01)\end{array}$ & $\begin{array}{c}37.65 \\
(37.85)\end{array}$ \\
\hline $\mathbf{T}_{4}$ & Eucalyptus globule & $\begin{array}{c}18.82 \\
(25.71)\end{array}$ & $\begin{array}{c}34.90 \\
(36.21)\end{array}$ & $\begin{array}{c}50.59 \\
(45.34)\end{array}$ & $\begin{array}{c}34.77 \\
(36.13)\end{array}$ \\
\hline $\mathbf{T}_{5}$ & Pongamia pinnata & $\begin{array}{c}14.90 \\
(22.71)\end{array}$ & $\begin{array}{c}31.76 \\
(34.31)\end{array}$ & $\begin{array}{c}47.84 \\
(43.76)\end{array}$ & $\begin{array}{c}31.50 \\
(34.14)\end{array}$ \\
\hline $\mathbf{T}_{6}$ & $\begin{array}{l}\text { Neemseed kernel extract } \\
\text { (NSKE) }\end{array}$ & $\begin{array}{c}13.73 \\
(21.75)\end{array}$ & $\begin{array}{c}25.49 \\
(30.32)\end{array}$ & $\begin{array}{c}41.57 \\
(40.15)\end{array}$ & $\begin{array}{c}26.93 \\
(31.26)\end{array}$ \\
\hline $\mathbf{T}_{7}$ & Bougainvillea glabra & $\begin{array}{c}12.16 \\
(20.41)\end{array}$ & $\begin{array}{c}20.00 \\
(26.56)\end{array}$ & $\begin{array}{l}36.08 \\
(36.92)\end{array}$ & $\begin{array}{c}22.75 \\
(28.48)\end{array}$ \\
\hline \multirow[t]{2}{*}{$\mathbf{T}_{8}$} & Tagates erecta & $\begin{array}{c}6.27 \\
(14.51)\end{array}$ & $\begin{array}{c}14.51 \\
(22.39)\end{array}$ & $\begin{array}{l}23.53 \\
(29.02)\end{array}$ & $\begin{array}{l}14.77 \\
(22.60)\end{array}$ \\
\hline & Mean & $\begin{array}{c}17.25 \\
(24.54)\end{array}$ & $\begin{array}{c}32.35 \\
(34.66)\end{array}$ & $\begin{array}{c}46.27 \\
(42.86)\end{array}$ & \\
\hline & & \multicolumn{2}{|c|}{ S.Em. \pm} & \multicolumn{2}{|c|}{ C.D.@1\% } \\
\hline & Treatment $(\mathbf{T})$ & \multicolumn{2}{|c|}{1.30} & \multicolumn{2}{|c|}{3.92} \\
\hline \multicolumn{2}{|r|}{ Concentration $(\mathrm{C})$} & \multicolumn{2}{|c|}{0.79} & \multicolumn{2}{|c|}{2.37} \\
\hline \multicolumn{2}{|c|}{$\mathbf{T} \times \mathbf{C}$} & \multicolumn{2}{|c|}{2.20} & \multicolumn{2}{|c|}{6.60} \\
\hline
\end{tabular}

* Arc sine transformed values 
Table.2 In vitro evaluation ITKs against Septoria lycopersici

\begin{tabular}{|c|c|c|c|c|c|}
\hline \multirow[t]{2}{*}{ Treatments } & \multirow[t]{2}{*}{ ITKs } & \multicolumn{4}{|c|}{ Per cent inhibition of spore germination } \\
\hline & & $5 \%$ & $10 \%$ & $15 \%$ & Mean \\
\hline $\mathbf{T}_{1}$ & Cow urine & $\begin{array}{c}56.67 \\
(48.83)^{*}\end{array}$ & $\begin{array}{c}63.33 \\
(52.73)\end{array}$ & $\begin{array}{c}76.67 \\
(61.12)\end{array}$ & $\begin{array}{r}65.56 \\
(54.06)\end{array}$ \\
\hline $\mathbf{T}_{2}$ & Panchagavya & $\begin{array}{c}50.00 \\
(45.00)\end{array}$ & $\begin{array}{c}60.00 \\
(50.77)\end{array}$ & $\begin{array}{c}73.33 \\
(58.90)\end{array}$ & $\begin{array}{r}61.11 \\
(51.42)\end{array}$ \\
\hline $\mathbf{T}_{\mathbf{3}}$ & Jeevamrutha & $\begin{array}{c}43.33 \\
(41.17)\end{array}$ & $\begin{array}{c}56.67 \\
(48.83)\end{array}$ & $\begin{array}{c}66.67 \\
(54.74)\end{array}$ & $\begin{array}{c}55.56 \\
(48.19)\end{array}$ \\
\hline $\mathbf{T}_{4}$ & Vermiwash & $\begin{array}{c}40.00 \\
(39.23)\end{array}$ & $\begin{array}{c}53.33 \\
(46.91)\end{array}$ & $\begin{array}{c}60.00 \\
(50.77)\end{array}$ & $\begin{array}{c}51.11 \\
(45.64)\end{array}$ \\
\hline $\mathbf{T}_{5}$ & $\begin{array}{l}\text { Turmeric } \\
\text { powder }\end{array}$ & $\begin{array}{c}36.67 \\
(37.26)\end{array}$ & $\begin{array}{c}40.00 \\
(39.23)\end{array}$ & $\begin{array}{c}53.33 \\
(46.91)\end{array}$ & $\begin{array}{c}43.33 \\
(41.17)\end{array}$ \\
\hline $\mathbf{T}_{6}$ & Buttermilk & $\begin{array}{c}33.33 \\
(35.26)\end{array}$ & $\begin{array}{c}36.67 \\
(37.27)\end{array}$ & $\begin{array}{c}46.67 \\
(43.09)\end{array}$ & $\begin{array}{c}38.89 \\
(38.59)\end{array}$ \\
\hline $\mathbf{T}_{7}$ & $\begin{array}{l}\text { Ginger rhizome } \\
\text { extract }\end{array}$ & $\begin{array}{c}26.67 \\
(31.09)\end{array}$ & $\begin{array}{c}33.33 \\
(35.26)\end{array}$ & $\begin{array}{c}43.33 \\
(41.17)\end{array}$ & $\begin{array}{r}34.44 \\
(35.94)\end{array}$ \\
\hline \multirow[t]{3}{*}{$\mathbf{T}_{8}$} & Biodigestor & $\begin{array}{c}20.00 \\
(26.56)\end{array}$ & $\begin{array}{c}26.67 \\
(31.09)\end{array}$ & $\begin{array}{c}33.33 \\
(35.26)\end{array}$ & $\begin{array}{c}26.67 \\
(31.09)\end{array}$ \\
\hline & Mean & $\begin{array}{c}38.33 \\
(38.25)\end{array}$ & $\begin{array}{c}46.25 \\
(42.85)\end{array}$ & $\begin{array}{c}56.67 \\
(48.83)\end{array}$ & \\
\hline & & \multicolumn{2}{|c|}{ S.Em. \pm} & \multicolumn{2}{|c|}{ C.D.@1\% } \\
\hline \multicolumn{2}{|c|}{ Treatment $(\mathbf{T})$} & \multicolumn{2}{|c|}{1.24} & \multicolumn{2}{|c|}{3.72} \\
\hline \multicolumn{2}{|c|}{ Concentration (C) } & \multicolumn{2}{|c|}{0.76} & \multicolumn{2}{|c|}{2.28} \\
\hline \multicolumn{2}{|c|}{$\mathbf{T} \times \mathbf{C}$} & \multicolumn{2}{|c|}{2.15} & \multicolumn{2}{|c|}{6.45} \\
\hline
\end{tabular}

* Arc sine transformed values

\section{Evaluation of ITKs}

Eight ITKs were used to test their efficacy in inhibiting the condial germination of $S$. lycopersici by using spore germination technique as detailed in Material and Methods. Among the three concentrations tested, the maximum inhibition of conidial germination was observed at 15 per cent concentration followed by 10 per cent and 5 per cent concentrations. Out of the eight ITKs tested against $S$. lycopersici, cow urine (76.67
$\%)$ at 15 per cent concentration was found to be superior in inhibiting germination of conidia of S. lycopersici which was on par with panchagavya $(73.33 \%)$ followed by jeevamrutha $(66.67 \%)$, vermiwash $(60.00 \%)$, turmeric powder (53.33\%), buttermilk $(46.67 \%)$, ginger rhizome extract $(43.33 \%)$ and the least inhibition was observed in biodigestor $(33.33 \%)$ at $15 \%$ concentration. Results from this experiment are presented in the Table 2, Plate 2 and Figure 2. 


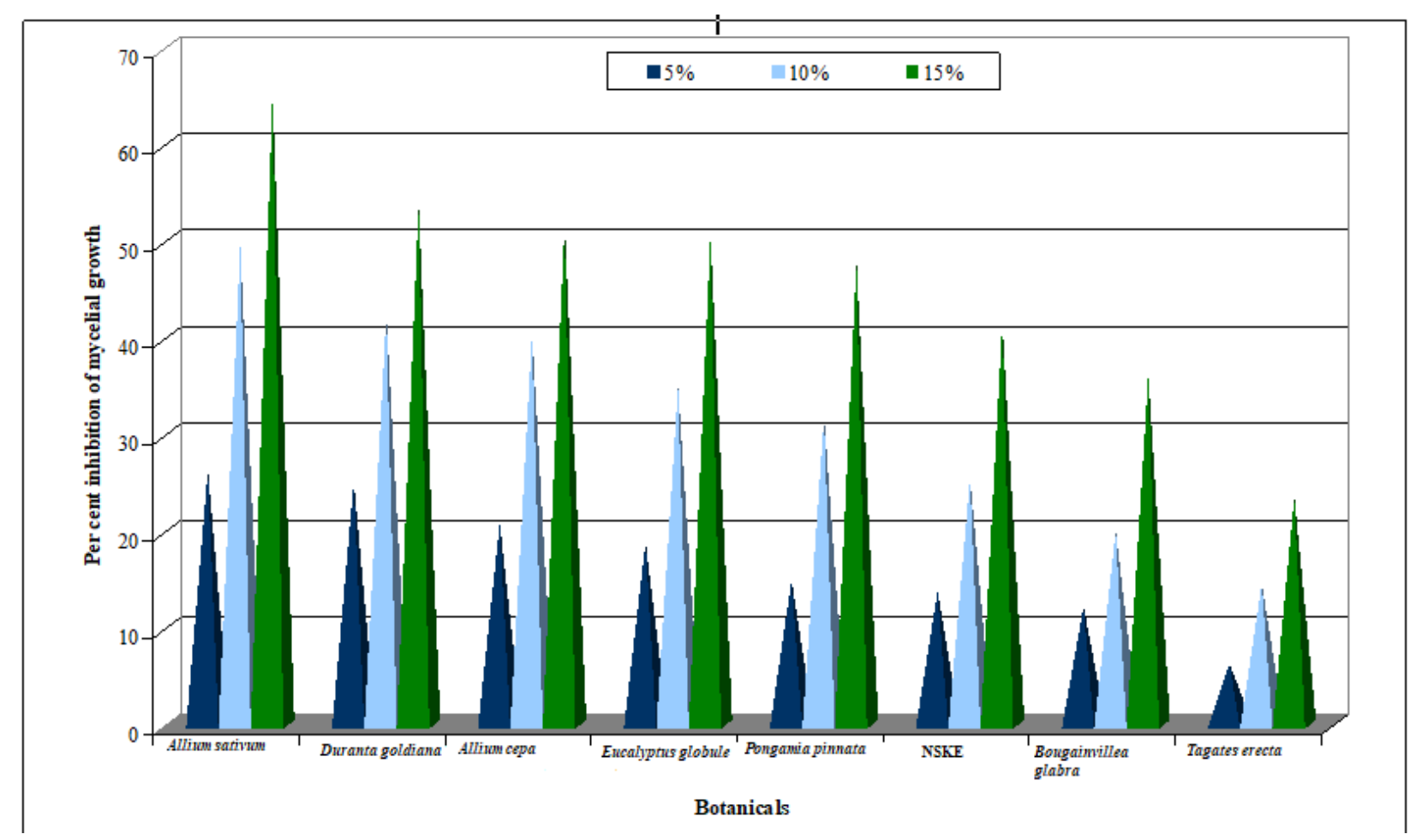

Fig.1 In Vitro evaluation of botanicals against Septoria Lycopersici

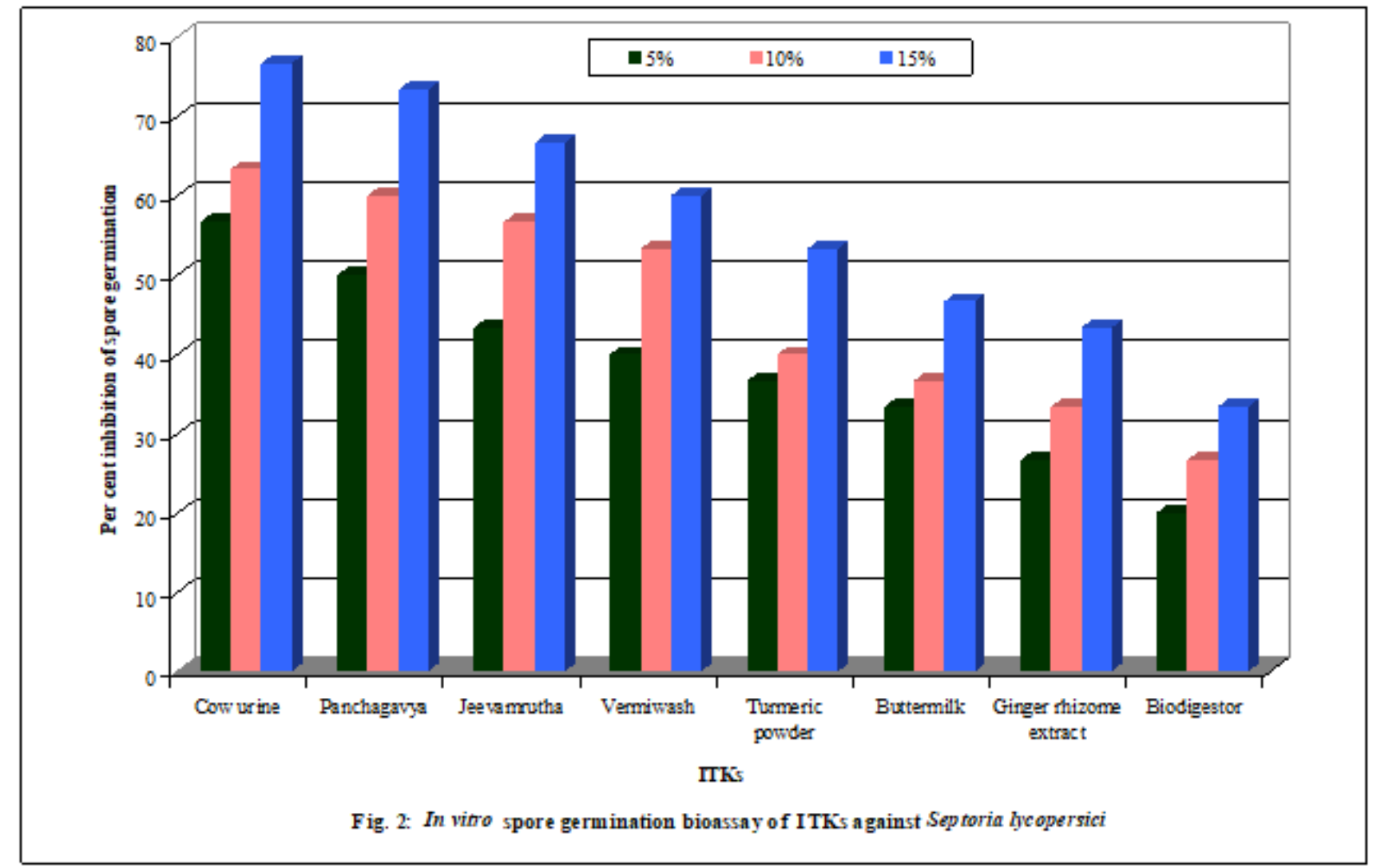

Fig.2 In Vitro spore germination bioassay of ITKs against Septoria Lycopersici 


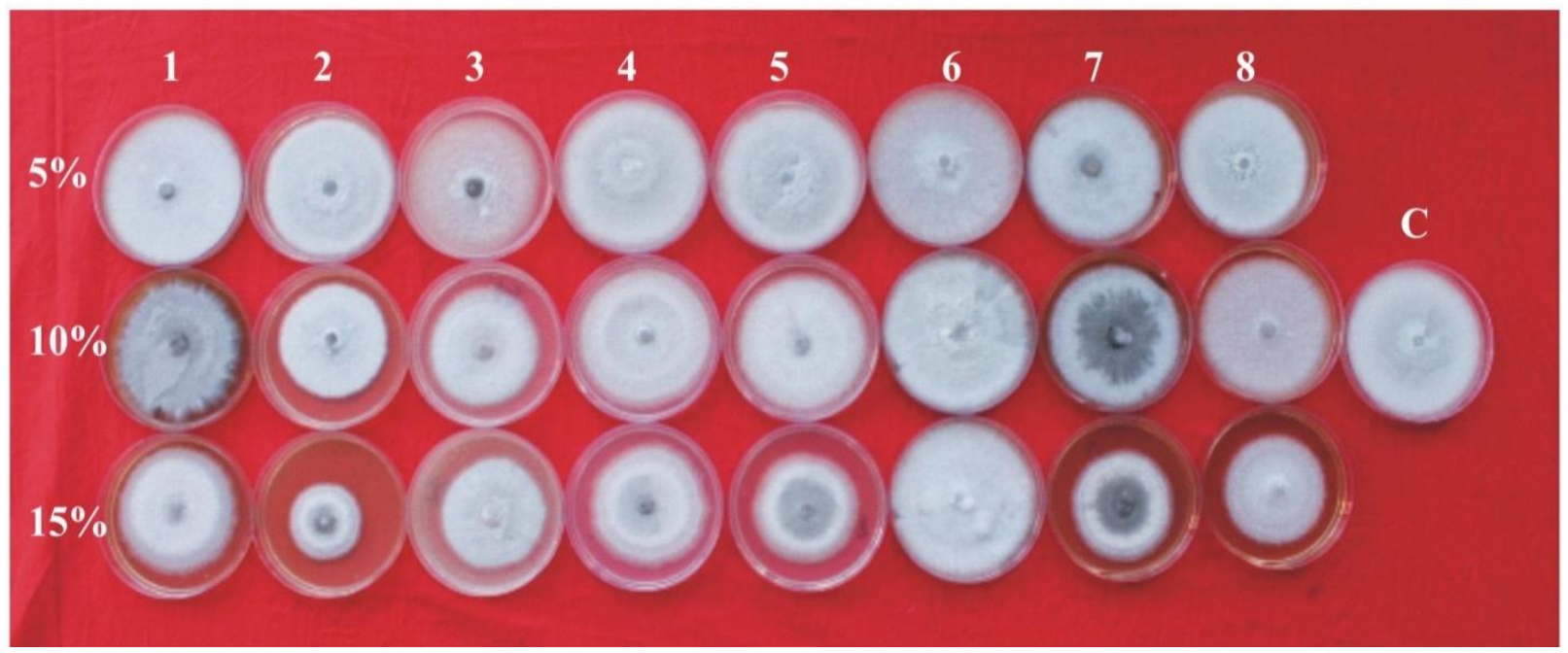

1. Bougainvillea glabra, 2. Allium sativum, 3. Durantagoldiana 4. NSKE 5. Allium cepa

6. Tagateserecta 7. Eucalyptus globule 8. Pongamiapinnata 9. Control

Plate.1 In vitro evaluation of botanicals against Septoria lycopersici

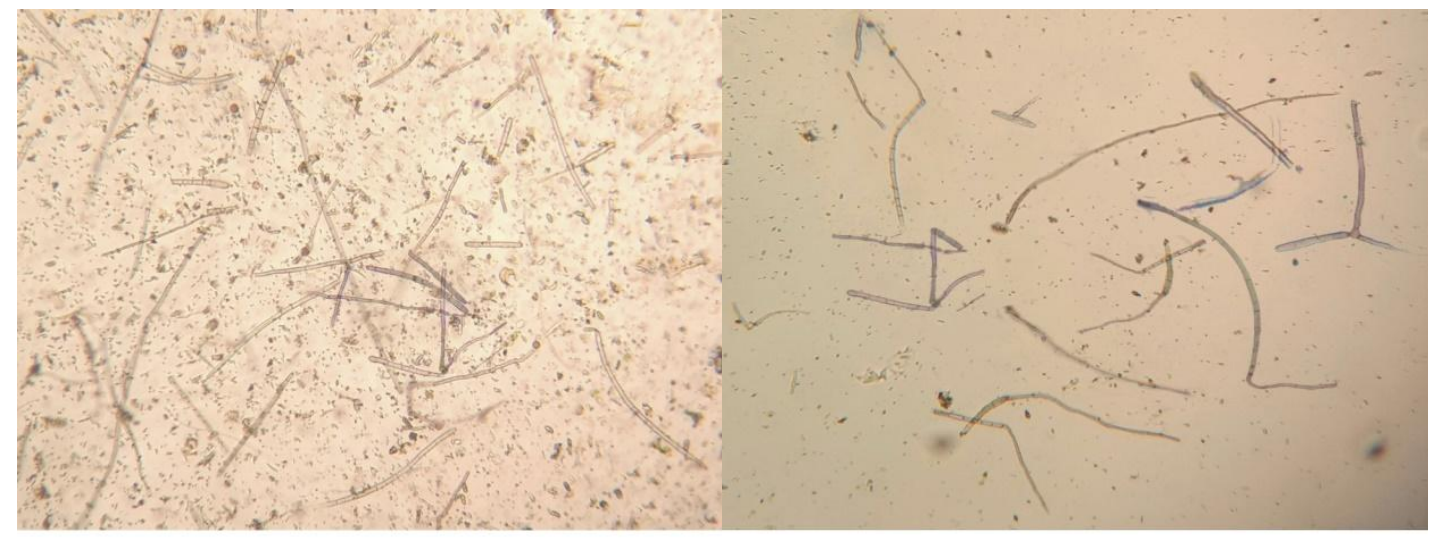

a) Cow urine @ 15\%

b) Untreated control

Plate.2 In vitro spore germination bioassay of ITKs against Septoria lycopersici

The results are in agreement with Savita et al., (2015) who found that cow urine at 15 per cent concentration was most effective against three fungal pathogens (Fusarium oxysporum, Rhizoctonia solani and Sclerotium rolfsii) of methi and bhendi. Basak et al., (2005) found that cow urine was very effective in controlling wilt disease of cucumber caused by Fusarium oxysporum f. sp. Cucumerinum and Fusarium solani f.sp. cucurbitae. Patel et al., (2015) found that cow urine was best against red rot disease of sugarcane Colletotrichum falcatum. The antifunal activity of cow urine might be due to the presence of dimethylamine, inorganic phosphorus. Janadik and Sharma (2016) reported that cow urine has magnificent antifungal power, growth enhancing and germicidal influence on plant pathogens. Cow urine is shown experimentally to possess various biological activities such as antidiabetic (Gururaja et al., 2011), antimicrobial (Upadhyay et al., 2010), antioxidant (Krishnamurthi et al., 2004), antitumor (Raja and Agarwal, 2010), molluscicidal (Kumar et al., 2011) and other. 


\section{References}

Basak, A. B., Lee, M. W. and Lee, T. S. 2002. Inhibitive activity of cow urine and cow dung against Sclerotinia sclerotiorum of cucumber.Mycobiology.30: 175-179.

Blancard, D., Laterrot, H., Marchoux, G. and Candresse, T. 1992. A colour handbook - tomato diseases: identification, biology and control. Manson Publishing Limited, London UK, p. 688.

Choulwar, A. B., Datar, V. V. 1988. Cost linked spray scheduling for the management of tomato early blight. Indian Phytopathol. 41(4): 603-606.

Cowan, M. M. 1999. Plant products as antimicrobial agents. Clin.Microbiol. Rev. 12: 564-582.

Elmer, W. H. and Ferrandino, F. J. 1995.Influence of spore density, leaf age, temperature, and dew periods on septoria leaf spot of tomato. Plant dis. 79 (3): 287-290.

Gururaja, M. P., Joshi, A. B., Joshi, H., Sathyanarayana, D., Subrahmanyanm, E. V. S and Chandrashekar, K. S. 2011. Antidiabetic potential of cow urine in streptozotocin-induced diabetic rats. Asian J. Tradit. Med. 6: 8-13.

Jandaik, S. and Sharma, V. 2016.Antifungal potential of panchagavya against soil borne fungal pathogens associated with capsicum nurseries. Int. J. Agri. Soil Sci.4 (2): 22-26.

Krishnamurthi, K., Dutta, D., Sivanesan, S. D. and Chakrabarti, T. 2004. Protective effect of distillate and redistillate of cow's urine in human polymorphonuclear leukocytes challenged with established genotoxic chemicals. Biomed. Environ. Sci. 17: 247-256.

Kumar, S., Singh D. K. and Singh, V. K. 2011.Molluscicidal effect of freezedried cow urine of Indian cow breeds against Lymnaea acuminata. J. Toxicol.
Sci. 3: 70-74.

Lal, M., Dabbas, M. R., Singh, S. K., Kumar, S. and Kumar, N. 2016. Efficacy of various bio agents and plant extract against Septoria lycopersici. Int. J. Plant Protect. 9 (1): 177-182.

Maheshwari, S. K., Gupta, P. C., Gandhi, S. K. 1991. Evaluation of different fungitoxicants against early blight of tomato (Lycopersicon esculentum Mill).Agricultural Science Digest Karnal.11(4): 201-202.

Murthy, N. B. K. and Amonker, S. V. 1974. Effect of natural insecticide from garlic (Allium sativum L.) and its synthetic form (diallyldisulphide) on plant pathogenic fungi. Indian J. Expt. Biol. 12: 208-209.

Nene, V. L. and Thapliyal, P. N. 1982.Fungicides in plant disease control. Oxford and IBH Pubi.Co. Pvt. Ltd, New Delhi, India. pp. 212-349.

Pankaj, K. and Singh, S. 2017. In vitro evaluation of fungicides and plant extract against Alternaria solani (Ellis) causing early blight in tomato (Lycopersicon esculentum Mill.). Int. J. Curr. Microbiol. App. Sci. 6 (9): 820827.

Patel, P., Shah, R., Bhasker, V. V., Modi, K. and Prajapati, V. S. 2015.Biological control of phytopathogenic fungus Colletotrichum falcatum using Bostaurus (cow) urine and dung. J. Bioche. Tech. 6 (3): 1040-1043.

Raja, W. and Agarwal, R. C. 2010. Chemopreventive potential of cow urine against 7, 12-dimethybenz (a) anthracene induced skin papillamagenesis in mice. Am. J. Cancer. Res. 3: 7-10.

Raut, A, A and Vaidya, A. 2018.Panchgavya and cow products: A trail for the holy grail, J. Ayurveda Integr. Med. 9: 64-66.

Rizinski, 1966.A contribution to the study of the biology and control of tomato leaf 
spot (Septoria lycopersici) in Vardar region. Engl. Summ. Insti. Phytopath. Eagreb.10 (2): 25-29.

Roopa, R. S., Yadahalli, K. B. and Kavyashree, M. C. 2014.Evaluation of natural plant extracts, antagonists and fungicides against early blight caused by Alternaria solani in vitro. The Bioscan. 9(3): 1309-1312.

Savita, J., Preeti, T. and Vikas, K. 2015.Efficacy of cow urine as plant growth enhancer and antifungal agent. Advances Agric. pp. 1-7.

Shravelle, V. G. 1961. The nature and use of modern fungicides. Burges Publication Company, Minneosota, USA. p. 308.

Singh, U. P., Pandey, V. N., Wagtner, K. G. and Singh, K. P. 1990.Antifungal activity of ajoene, a constituent of garlic (Allium sativum). Can. J. Bot. 68: 13541356.

Schulzova, V. and Hajslova, J.
2007.Biologically active compounds in tomatoes from various fertilization systems, $3^{\text {rd }}$ QLIF Congress, Hohenheim, Germany.

Sokhi, S. S., Munshi, G. D., Grewal, R. K, Thind, T. S. and Sandhu, KS. 1991. Current fungal disease problems of important vegetables in India. Basal Research for crop disease management. (Ed. Vidhyasekaram, P.). Daya publishing house, Delhi. Pp. 409.

Upadhyay, R. K., Dwivedi, P. and Ahmad. S. 2010. Antimicrobial activity of photoactivated cow urine against certain pathogenic bacterial strains. Afr. $J$. Biotechnol. 9: 518-522.

Vincent, J. M., 1947. Distortion of fungal hypae in the presence of certain inhibitors. Nature. 159: 239-241.

Weber, G. F., 1982. Septoria disease of wheat, Phytopathology.72: 593-596.

\section{How to cite this article:}

Sindushree. D. R., Gurudatt M. Hegde and Yashoda R. Hegde. 2020. Invitro Evaluation of Botanicals and ITKs against Septoria lycopersici Causing Septoria Leaf Spot of Tomato. Int.J.Curr.Microbiol.App.Sci. 9(04): 407-415. doi: https://doi.org/10.20546/ijcmas.2020.904.049 